\title{
THE BEAR HILLS PRAIRIE FIRE: ONE YEAR LATER
}

\section{J. FRANK ROY, 650 Costigan Way, Saskatoon SK S7J 3R2}

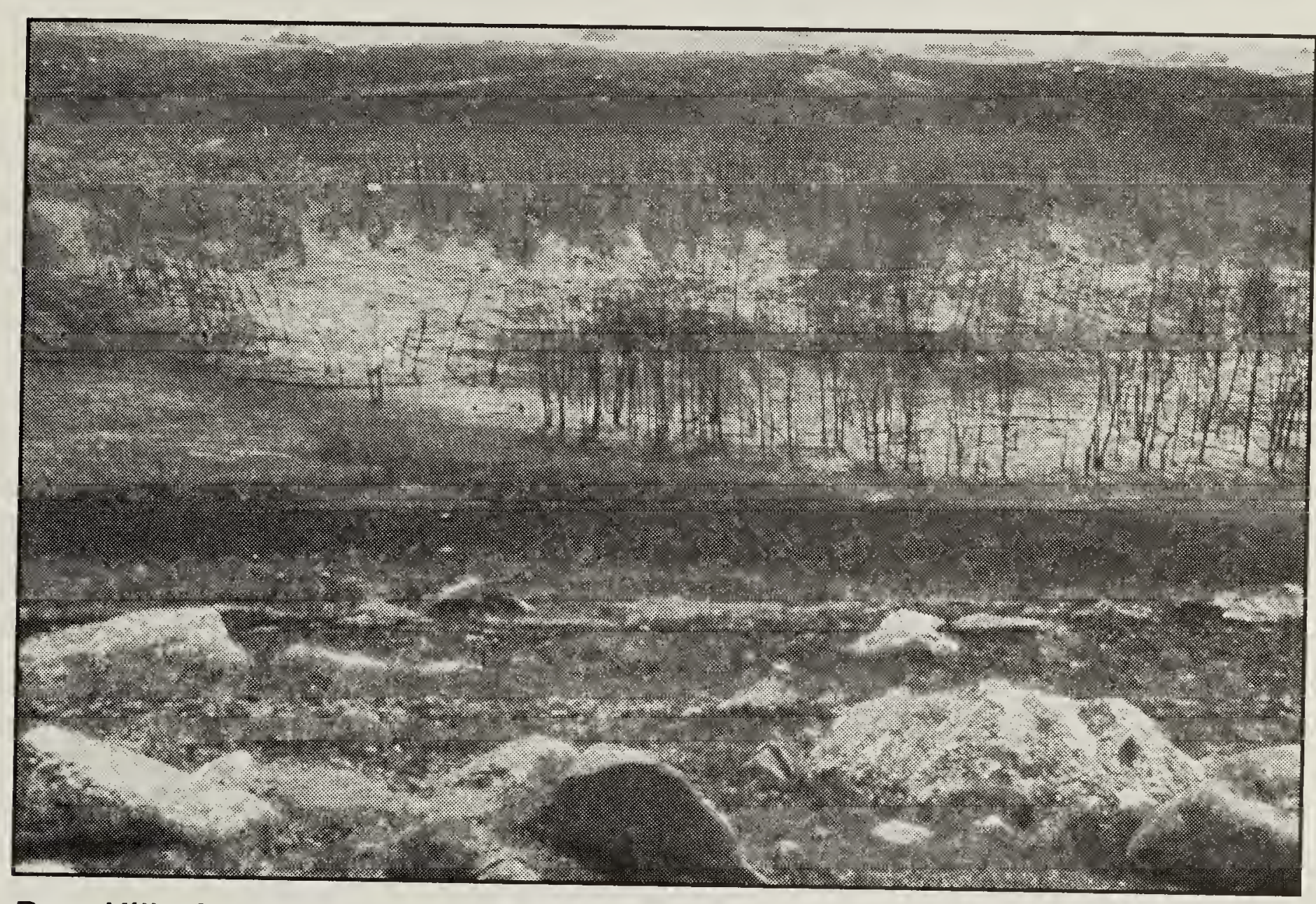

We rarely hear about prairie fires these days, but they were once commonplace throughout southern Saskatchewan. Ignited by lightning or set sometimes by Plains Indians, fires raced through dry grass over vast areas of prairie every spring and fall. Beginning about 1880 , a thin trickle of settlers from Eastern Canada, the United States and Europe began to move in, and shortly after 1900 the trickle became a torrent. By 1920, two thirds of Saskatchewan's grassland had disappeared under the plow. And with the resultant complex of cultivated fields and roads, prairie fires were almost entirely eliminated.
Today, less than a quarter of the province's original grassland remains, almost all of it in community and PFRA pastures or the ranch land of westcentral, south western and extreme southern Saskatchewan. The Bear Hills, approximately $100 \mathrm{~km}$ southwest of Saskatoon, boast some of the largest remnant stretches of virgin prairie in this part of the province. Crossed by Highway 4 between Rosetown and Biggar, the hills extend from south of Perdue west at least to Ruthilda.

On September 4, 1998, a fire, originating in a Coulee on the north slope of the Bear Hills, $16 \mathrm{~km}$ east of 
Highway 4, developed into one of the largest and most spectacular prairie fires within memory. Before it was finally extinguished on September 7 , it had burned all or part of nearly seven sections of land, over 1740 hectares (4,300 acres).

The alarm went out about 2:00 on Friday afternoon. Fanned by a fierce northwest wind, the fire was soon racing across the tops of the hills, heading south and east. Towering smoke could be seen for 30 kilometres. Local farmers with tractors, trucks, water tanks, cultivators and disks; villagers from the entire area; and five fire departments (Harris, Tessier, Perdue, Biggar and Rosetown-R. M. Marriott) converged on the hills. No one knows how many people turned out (at one time the line of cars extended all the way back to Highway 7) but at least two hundred fought the fire and hundreds more watched, fascinated. Singly and in crews, men plowed fireguards in intense heat and almost impenetrable smoke, pumped water on the hottest spots, lit backfires and worked until long after dark. Brian Longworth, a rancher on the south side of the hills, recalls that "the biggest challenge both days was communication; no one knew where anyone else was." Local women brought food and drinks to exhausted, smoke-blackened crews. Finally, well after midnight, firefighters had the blaze under control. September 5 was devoted to clean-up, putting out small fires still burning in aspen groves and fence lines.

Who could have imagined that two days later, on September 7 , the fire would begin again, this time at the east end of the hills? Primed by a fierce southeast wind, it tore through the north half of the hills which had escaped the first fire. After a day's struggle, firefighters contained the blaze. As one man put it, "There was nothing else left to burn."

The east end of the Bear Hills was a picture of desolation: the hills - now

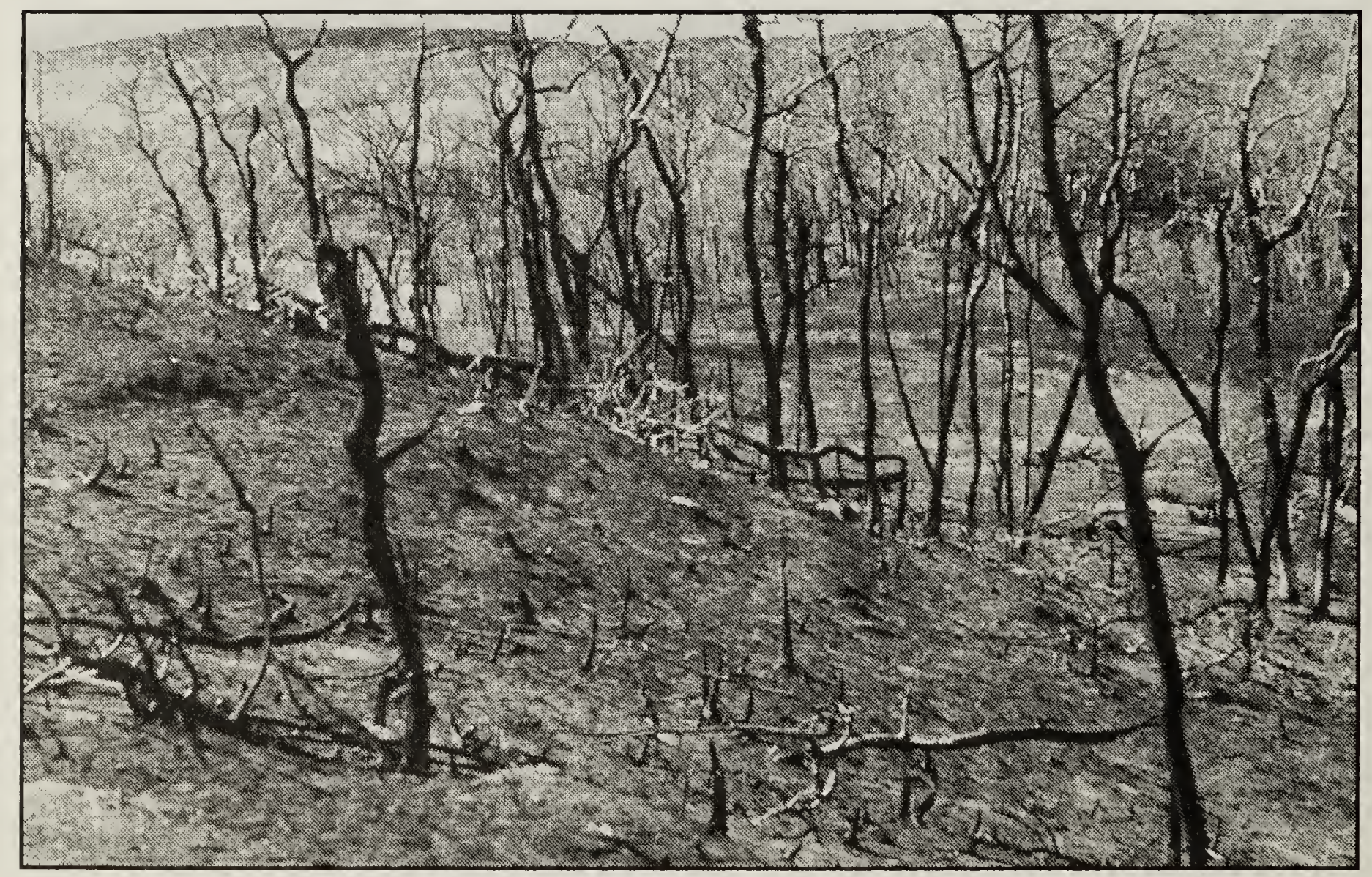

"Bare ruined choirs where late the sweet birds sang", Bear Hills SK 15 September 1998

J. Frank Roy 
ominously silent - charred black, dotted with stark white stones; on the crests, burnt-off fence posts clinging to barbed wire; in the hollows, still too hot to walk in, stark dead poplars and the dense gray ash of snowberry and willow; here and there, small pockets of yellow and green - grass and bush that had escaped the vagaries of a wind-driven blaze or been saved by firefighters.

Fortunately, no lives were lost, no buildings burned. The fire had been stopped as it reached the lower flanks of the hills, sometimes within metres of farm buildings. People from four municipalities and half a dozen towns had rallied to the call and won the battle against fire and wind. There would be costs: damaged machinery, fences to replace; valuable pasture lost for an uncertain period of time. The unanswered question: What would the Hills look like in 1999 and the years to follow?

A first visit on April 22, 1999 gave some indication. Recovery would be uneven. The hills were still essentially black; but in places, particularly where grass had been grazed before the fire and, as a result, the heat less intense, a faint hint of green indicated renewal had already begun. As we walked the hills, several small butterflies and moths flew by; occasionally a grasshopper jumped up in front of us. A few crocuses had emerged, each bearing a maximum of two or three blossoms, but larger than usual, perfectly formed, very open. Moss Phlox, ordinarily abundant in the hills, was noticeably absent, its shallow root systems apparently completely destroyed. But the first leaves of Threeflowered Avens indicated there would likely be full recovery of that species. In the burnt-out aspen groves, there were still no signs of life; no buds had developed, no catkins formed. It was yet too early to tell whether new poplars

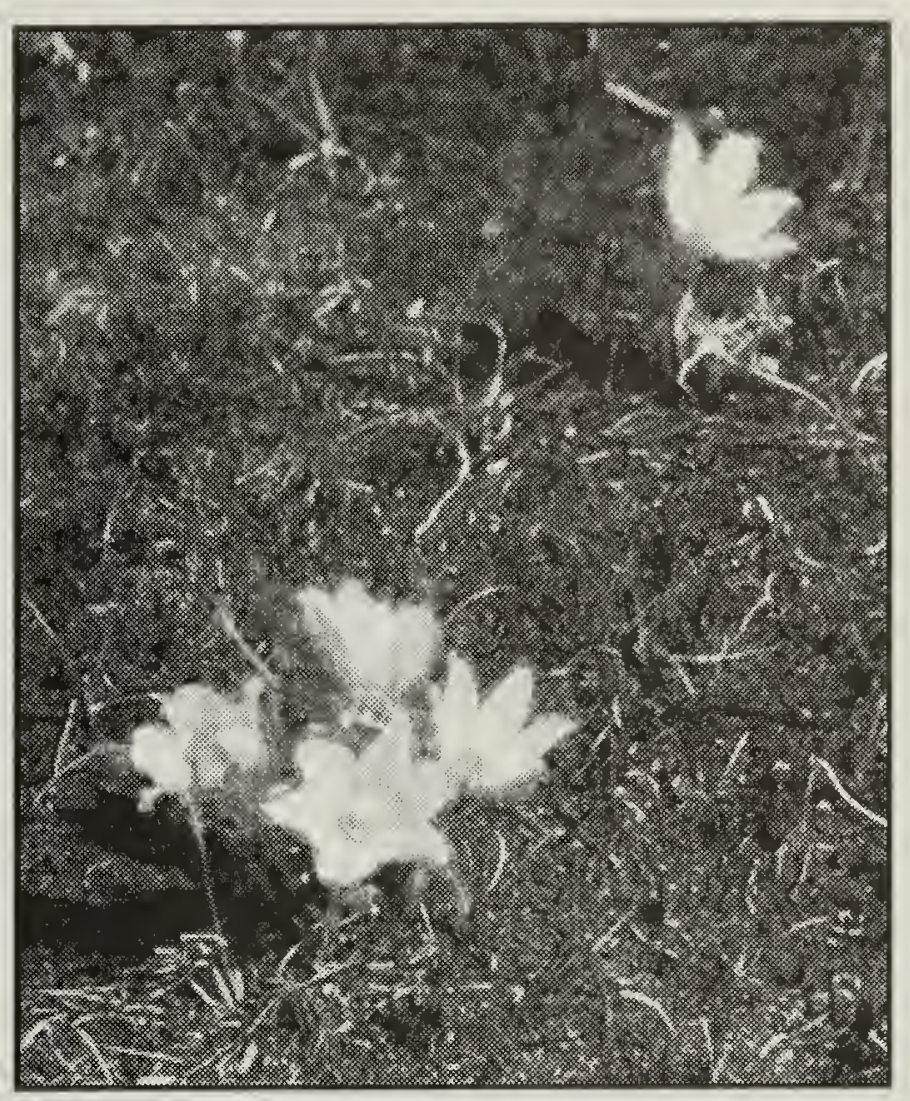

First growth after the fire, Bear Hills SK, 22 April 1999

J. Frank Roy

would emerge from the roots. Amazingly, fresh droppings and feathers indicated that Sharp-tailed Grouse had returned to dance at an ancestral lek, but where, we wondered, would the females find sufficient cover to locate their nests?

Less than two months later, on July 10 , we visited the hills a second time. Near ideal growing conditions had transformed blackened prairie into a green blanket spangled with flowers. Among them were late-blooming anemones, a profusion of Three-flowered Avens, Harebell, yarrow, potentilla, a variety of vetches, an abundance of Yellow Umbrella-plants, extensive patches of Scarlet Mallow, and fragrant Prairie Roses, both pink and white, growing close to the ground. Weeds, among them escapees from farmer's fields like Russian Thistle, mustard and pigweed, were growing more profusely than ever, in some places crowding out recovering grasses, an obvious cause of concern for local ranchers. Aspen shoots, already up to $50 \mathrm{~cm}$ tall, had sprung up at the base of dead parent 


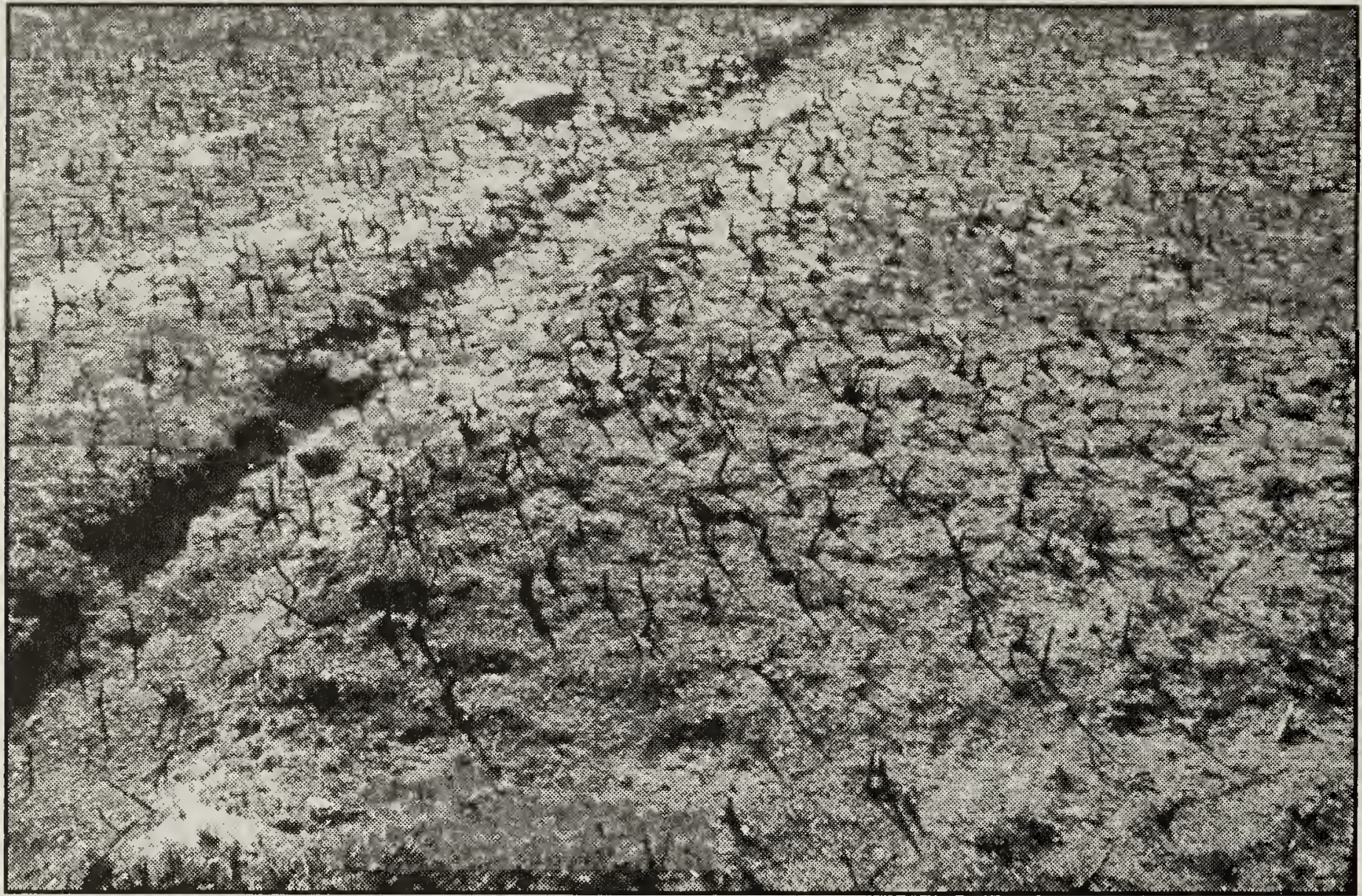

Western Snowberry (Buckbrush), Bear Hills SK, 15 September 1998

J. Frank Roy

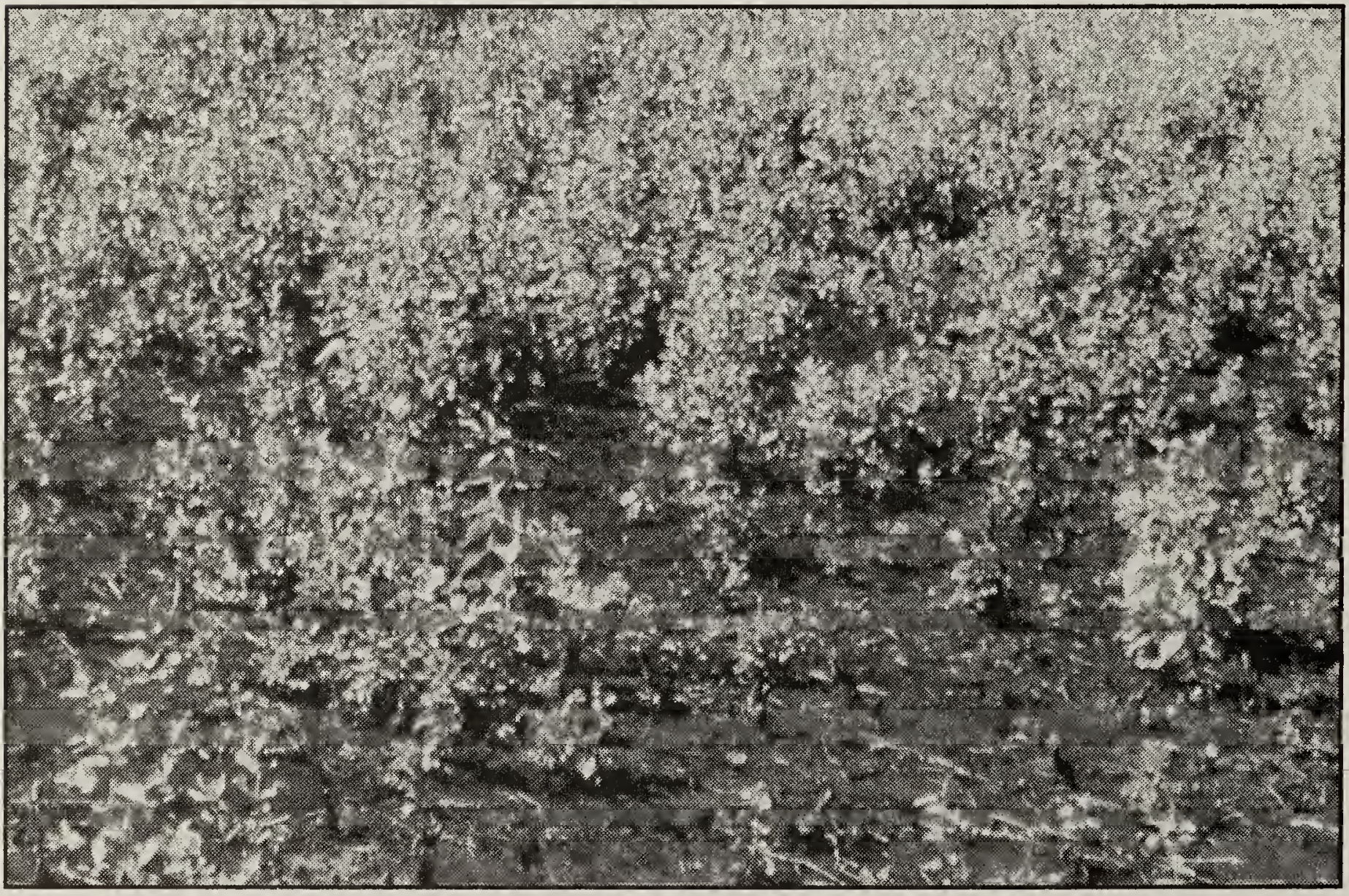

Western Snowberry (Buckbrush) rejuvenation after fire, Bear Hills SK, 10 July 1999

J. Frank Roy 


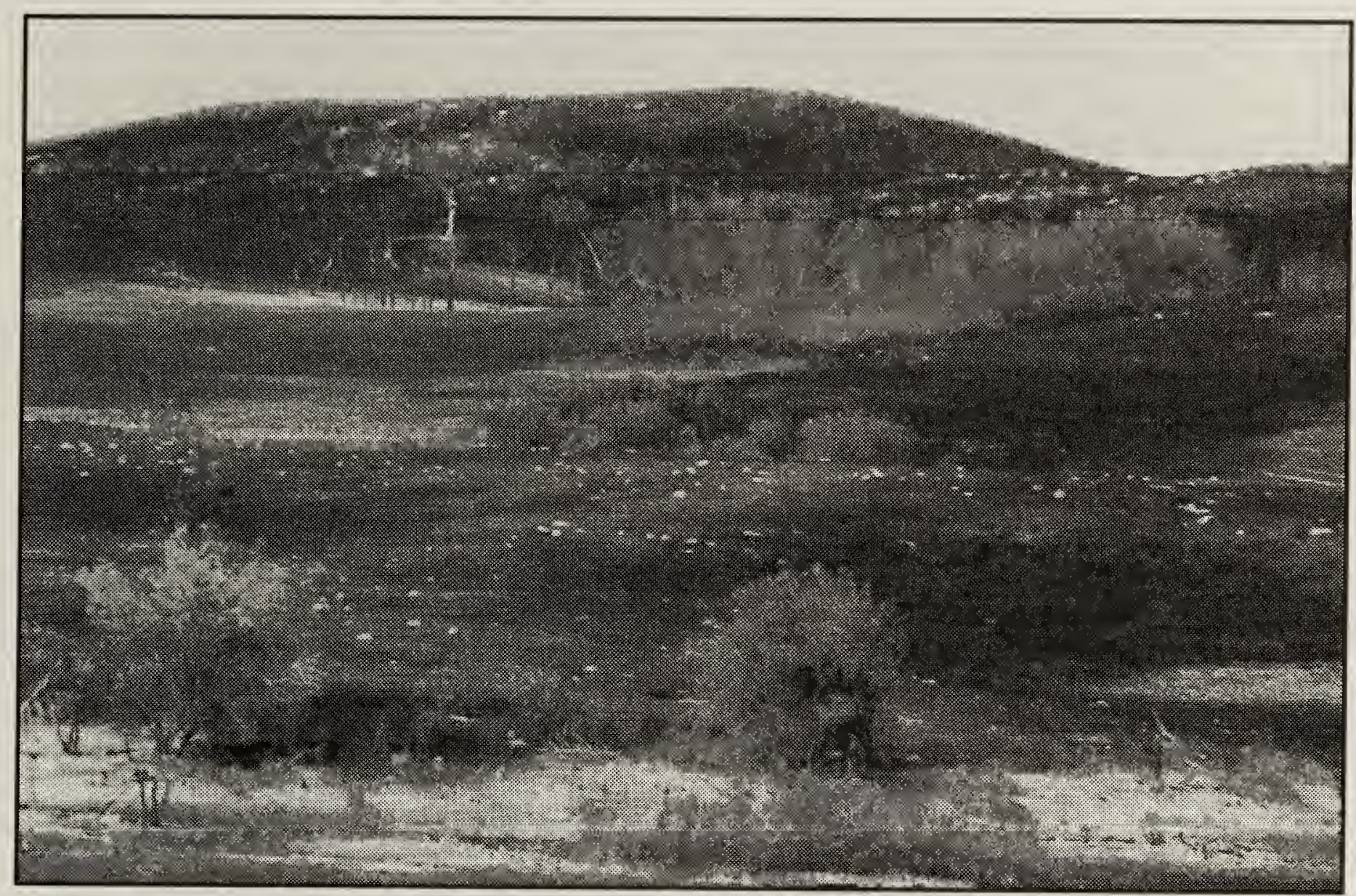

Bare soil and ash, Bear Hills SK, 15 September 1998

George Tosh

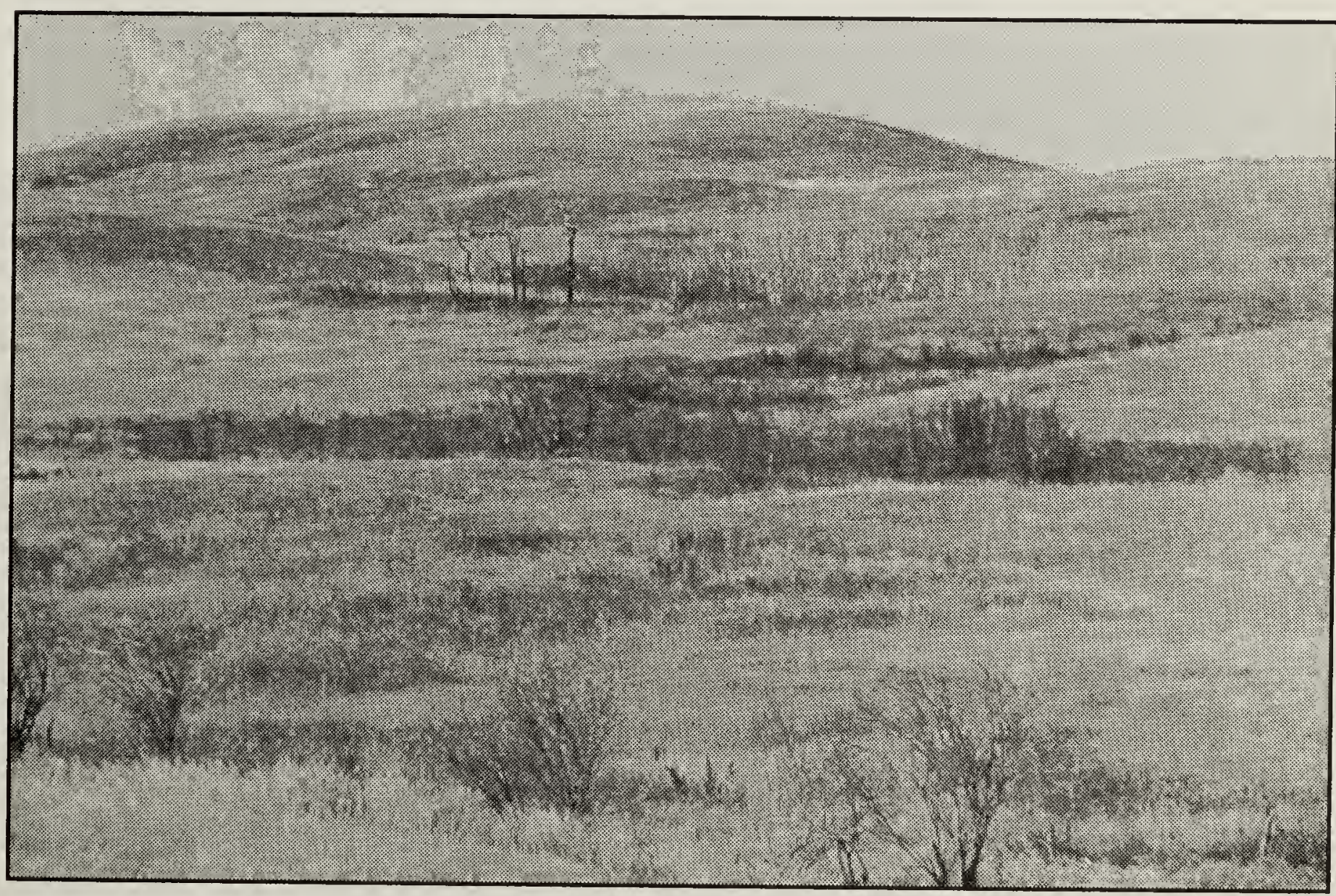

First season's growth after the fire, Bear Hills SK, 20 August 1999

George Tosh 
trees or from extended roots. On the fringes of burned-out depressions, Western Snowberry was already pushing through the ashes, its gray-green leaves twice normal size. But Wolf Willow, once widely distributed, showed no signs of life.

Deer (both Mule and White-tailed) were foraging in the new growth; a Jack Rabbit skipped across a trail in front of us and a watchful Coyote slipped unobtrusively over a hill. Surprisingly, a number of birds occupied the bare, dead aspens. Among those noted were Mountain Bluebirds, Eastern and Western kingbirds, House Wrens, American Goldfinches, Lark, Vesper and Clay-colored sparrows, and a flicker. Although we found no evidence of nesting, the birds seemed to be on territory. Would they delay nesting until next year?
It's too early yet to determine the final results of the Bear Hills fire. Obviously, recovery has been much more rapid than agrology experts had predicted. The Hills remain a fascinating place to visit, particularly now that we can observe the changes wrought by a massive prairie fire. (This article was reproduced from the Saskatoon Sun)

Scientific names of plants mentioned in this article: anemones (Anemone species), crocus (Anemone patens), Harebell (Campanula rotundifolia), Moss Phlox (Phlox hoodii), potentilla (Potentilla species), Scarlet Mallow (Sphaeralcea coccinea), Three-flowered Avens (Geum triflorum), Western Snowberry (Symphoricarpos occidentalis), Wolf Willow (Elaeagnus commutata), yarrow (Achillea species), Yellow Umbrella-plant (Eriogonum flavum).

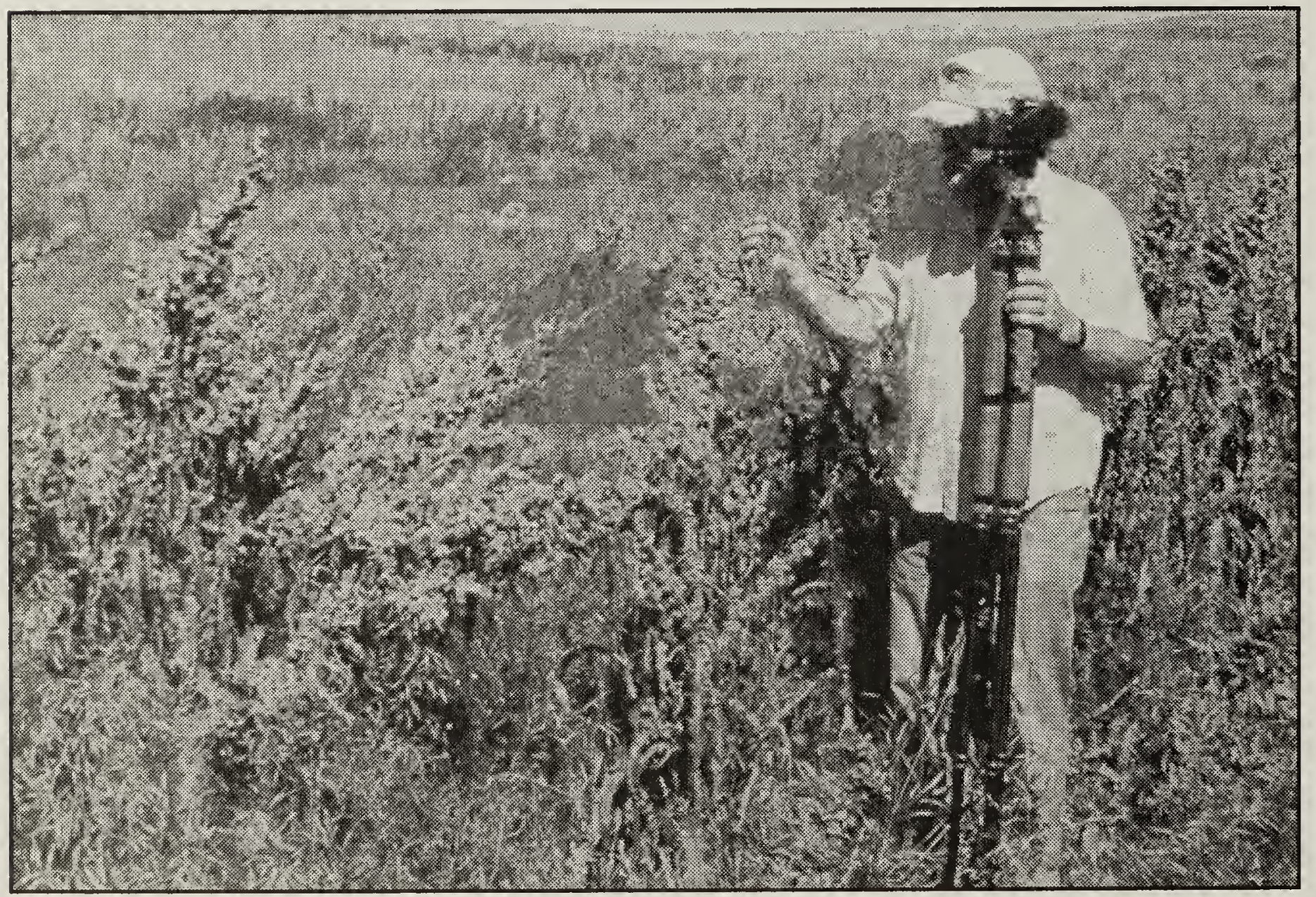

George Tosh (6'2") beside dock plant, Bear Hills SK, 20 August 1999.

J. Frank Roy 